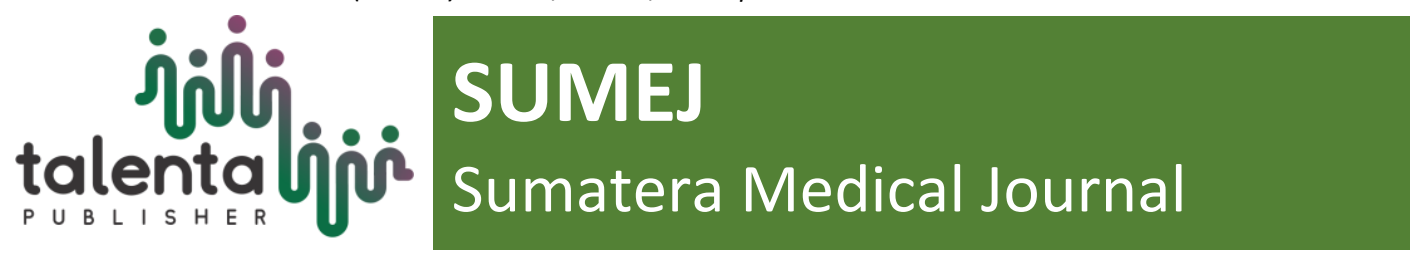

\title{
Profile of Teenage Pregnancy in H. Adam Malik Hospital Medan in 2011-2015
}

\author{
K. Sukatendel $I^{*}$, I. H. Effendi, ${ }^{2}$ S. Dina ${ }^{3}$, S. A. Nasution ${ }^{4}$, J. Marpaung, I. \\ Hamidi $^{6}$
}

1,2,3,4,5,6 Obstetrics and Gynecology Department, Medical Faculty University of North Sumatera, H. Adam

Malik Hospital Medan

\begin{abstract}
Many of the teenagers who enter pregnancy would cause a decline in health and nutritional status. Delivery at an early age was associated with a greater health risk for the mother. To assess the profile of teenage pregnancy in H. Adam Malik Hospital Medan year 2011-2015. This study was conducted with descriptive study design using secondary data from medical records. There were 128 patients who became pregnant in their teens. Then the data were tabulated and presented in the form of frequency distribution table and were analyzed descriptively. Most pregnant women came to the hospital for parturition (60.1\%) followed by preeclampsia / eclampsia (14.8\%). The way of delivery of pregnant adolescent women was vaginal $(52.3 \%)$ followed by cesarean $(36.7 \%)$. There was no significant relationship between adolescent age of pregnant and newborn weight. There was no significant relationship between the age of the adolescent and method of delivery. Most teenage pregnancy occured between 17-19 years. Most pregnant teenagers delivered vaginally, and most of the newborns were normoweight.
\end{abstract}

Keyword: Teenage Pregnancy, Pregnancy Profile

Abstrak. Banyak remaja yang memasuki kehamilan akan menyebabkan penurunan status kesehatan dan gizi. Persalinan pada usia dini dikaitkan dengan risiko kesehatan yang lebih besar bagi ibu. Untuk menilai profil kehamilan remaja di Rumah Sakit H. Adam Malik Medan tahun 2011-2015. Penelitian ini dilakukan dengan desain penelitian deskriptif menggunakan data sekunder dari rekam medis. Ada 128 pasien yang hamil di usia remaja. Kemudian data ditabulasikan dan disajikan dalam bentuk tabel distribusi frekuensi dan dianalisis secara deskriptif. Sebagian besar wanita hamil datang ke rumah sakit untuk proses kelahiran $(60,1 \%)$ diikuti oleh preeklamsia / eklamsia (14,8\%). Cara pengiriman wanita hamil remaja adalah vagina $(52,3 \%)$ diikuti oleh sesar $(36,7 \%)$. Tidak ada hubungan yang signifikan antara usia remaja hamil dan berat badan baru lahir. Tidak ada hubungan yang signifikan antara usia remaja dan metode persalinan. Sebagian besar kehamilan remaja terjadi antara 17-19 tahun. Sebagian besar remaja hamil melahirkan melalui vagina, dan sebagian besar bayi baru lahir normal.

Kata Kunci: Kehamilan Remaja, Profil Kehamilan

Received [20 February 2018] | Revised [30 May 2019] | Accepted [\#\#\#\#\#\#\#\#\#]

${ }^{*}$ Corresponding author at: Faculty of Medicine, Universitas Sumatera Utara, Medan, Indonesia 


\section{Introduction}

Teenage pregnancy is a pregnancy that occurs in women between the ages of 14 - 19 years either within or without marriage [1]. Adolescence is a period of transition from childhood to adulthood where rapid physical, mental, psychosocial changes occur on various aspects of life. Physical changes experienced by adolescents are associated with the production of sex hormones in the body that result in the emergence of emotional and sexual impulses, due to curiosity and tendency to try new things [2].

Approximately 16 million teenage girls aged between 15 and 19 years give birth annually, accounting for about $11 \%$ of all births worldwide. Approximately $95 \%$ of births occur in developing countries [3]. Evidence suggested that a large number of girls aged between 10-14 years also give birth in some countries. A survey analysis conducted in 51 studies from the mid1990 s to the 2000s showed that up to $10 \%$ of adolescents became mothers by the age of 16 , with the highest rates in sub-Saharan Africa and South-Central and Southeast Asia. In Indonesia the average teenage pregnancy occured at the age of 14-19 years, obtained from the survey of knowledge, attitude, and practices [4].

Pregnancy at an early age is associated with a greater health risk for the mother. In developing countries, complications of pregnancy and childbirth are the leading causes of death in young women aged 15-19 [5]. As most teenage pregnancies are undesirable, many end up in abortion often unsafe abortions. An estimated 3 million unsafe abortions occur globally each year among girls ages 15-19 [6].

\section{Methodology}

This research is descriptive study of secondary data, that is collection and analysis of data based on medical record of adolescent pregnant patient treated in Obstetrics and Gynecology Department of H. Adam Malik Hospital Medan in the period of 1 January 2011 - 31 December 2015.

The sample of this study amounted to 128 people, with inclusion criteria of pregnant women with age under 20 years in Obstetrics and Gynecology Section in the period January 1, 2011 December 31, 2015 and had a complete medical record.

\section{Results and Discussion}

This study was conducted in H. Adam Malik Hospital Medan in the period of 1 January 2011-31 December 2015. The number of samples that met the criteria were as many as 128 patients. 
Table 1 Teenage Pregnancy Characteristics

\begin{tabular}{|c|c|c|}
\hline Characteristics & Frequency (n) & Persentage (\%) \\
\hline \multicolumn{3}{|l|}{ Age (year) (mean) } \\
\hline $13-14(14 \pm 0)$ & 2 & 1,6 \\
\hline $15-16(15,8 \pm 0,42)$ & 10 & 7,9 \\
\hline $17-19(18,35 \pm 0,76)$ & 116 & 91,5 \\
\hline \multicolumn{3}{|l|}{ Education } \\
\hline Elementary & 31 & 24,2 \\
\hline Junior High & 61 & 47,7 \\
\hline Senior High & 36 & 28,1 \\
\hline \multicolumn{3}{|l|}{ Occupation } \\
\hline Housewife/jobless & 119 & 92,9 \\
\hline Farmer & 2 & 1,6 \\
\hline Student & 3 & 2,3 \\
\hline College Student & 1 & 0,8 \\
\hline Entrepreneur & 3 & 2,3 \\
\hline \multicolumn{3}{|l|}{ Marital Status } \\
\hline Not married & 6 & 4,7 \\
\hline Married & 122 & 95,3 \\
\hline \multicolumn{3}{|l|}{ Pregnancy status } \\
\hline Primiparous & 123 & 96,1 \\
\hline 2nd pregnancy & 5 & 3,9 \\
\hline Total $(\mathrm{N})$ & 128 & 100 \\
\hline
\end{tabular}

Table 2 Characteristics of Teenage Pregnancy Based on Diagnosis

\begin{tabular}{lcc}
\hline Diagnosis & Frequency $(\mathbf{n})$ & Persentage $\mathbf{( \% )}$ \\
\hline Labor & 77 & 60.1 \\
Obstructed Labor & 7 & 5.5 \\
Inadequate pelvis & 12 & 9.4 \\
Preeclampsia/Eclampsia & 19 & 14.8 \\
Breech presentation & 6 & 4.7 \\
Twin pregnancy & 3 & 2.3 \\
Prolonged Second Stage & 4 & 3.1 \\
Total & 128 & 100 \\
\hline
\end{tabular}

The table above suggested that most diagnoses in pregnant women were in labor $(60.1 \%)$ followed by preeclampsia / eclampsia (14.8\%) and the least with twin pregnancy diagnosis $(2.3 \%)$ and prolonged second stage $(3.1 \%)$. 
Table 3 Characteristics of Teenage Pregnancy Based on Birth Weight

\begin{tabular}{lll}
\hline Birth weight & Frequency $(\mathbf{n})$ & Persentage $(\%)$ \\
\hline$<2500$ grams & 34 & 26.6 \\
$\geq 2500$ grams & 94 & 73.4 \\
Total & 128 & 100 \\
\hline
\end{tabular}

Based on birth weight, most of the babies who were born were $\geq 2500$ grams (normoweight) $(73.4 \%)$, more than babies born with weight $<2500$ grams $(26.6 \%)$.

Table 4 Distribution of APGAR Score in Teenage Pregnancy

\begin{tabular}{lll}
\hline APGAR SCORE & Frequency $(\mathbf{n})$ & Persentage $(\%)$ \\
\hline$<3$ & 0 & 0 \\
$3-6$ & 5 & 3.9 \\
$>6$ & 123 & 96.1 \\
Total & 128 & 100 \\
\hline
\end{tabular}

Based on the table above, babies born to teenage girls mostly had the Apgar score $>6(96.1 \%)$ while Apgar score 3-6 were 3.9\%.

Table 5 Relationship Between Age of Pregnancy and Method of Delivery

\begin{tabular}{|c|c|c|c|c|}
\hline \multirow{2}{*}{ Delivery method } & \multicolumn{2}{|l|}{ Age group } & \multirow{2}{*}{-Total } & \multirow{2}{*}{$\mathbf{p}$} \\
\hline & $<18$ years & $\geq 18$ years & & \\
\hline Vacuum extraction & $0(0 \%)$ & $4(100 \%)$ & $4(100 \%)$ & \\
\hline Spontaneous vaginal & $13(24.7 \%)$ & $58(75.3 \%)$ & $71(100 \%)$ & \\
\hline Cesarean delivery & $19(27.7 \%)$ & $34(72.3 \%)$ & $53(100 \%)$ & 0.869 \\
\hline Total (Fisher Exact) & $32(25.0 \%)$ & $96(75.0 \%)$ & $128(100 \%)$ & \\
\hline
\end{tabular}

The table above showed that in adolescents who were pregnant at $<18$ years old, there were more cases of cesarean delivery $(27.7 \%)$ whereas pregnant teenagers aged 18 years and over were performed vacuum extraction (100\%), followed by PSP (75.3\%). Statistically with Fisher exact test obtained $\mathrm{p}$ value $>0.05$ which showed no significant relationship between adolescent age pregnant with mode of delivery.

Table 6 Relationship Between Age of Pregnancy and Newborn Weight

\begin{tabular}{|c|c|c|c|c|}
\hline \multirow{2}{*}{ Age } & \multicolumn{3}{|c|}{ Newborn weight } & \multirow{2}{*}{$\mathbf{p}^{*}$} \\
\hline & $<2500$ grams & $\geq 2500$ grams & Total & \\
\hline \multirow{2}{*}{$13-14$ years } & 2 & 0 & 2 & \\
\hline & $100 \%$ &, $0 \%$ & $100 \%$ & \\
\hline \multirow[t]{2}{*}{$15-16$ years } & 3 & 7 & 10 & \\
\hline & $30 \%$ & $70 \%$ & $100 \%$ & 0.086 \\
\hline \multirow[t]{2}{*}{17 - 19 years } & 29 & 87 & 116 & \\
\hline & $25 \%$ & $75 \%$ & $100 \%$ & \\
\hline Total & 34 & 94 & 128 & \\
\hline
\end{tabular}

Based on the table above, in adolescents who were pregnant at the age of 13-14 years, all gave birth to babies weighing <2500 gram (100\%), whereas in adolescents who were pregnant at the age of $15-16$ years most babies weighed $\geq 2500 \mathrm{grm}(70 \%)$, as well as in adolescents who were 
pregnant at the age of 17-19 years (75\%). Statistically with Chi Square test obtained p value > 0.05 which showed no significant relationship between adolescents who were pregnant with birth weight.

Table 7 Relationship Between Method of Delivery and Referral Status

\begin{tabular}{llllll}
\hline \multirow{2}{*}{ Delivery method } & \multicolumn{2}{l}{ Status Rujukan } & Total & \multirow{2}{*}{$\mathbf{p}^{*}$} \\
\cline { 2 - 6 } Vacuum extraction & 1 & 2 & 1 & 4 & \\
Sidwife & Doctor & Self-admit & $100 \%$ & \\
Spontaneous vaginal & $25 \%$ & $50 \%$ & $25 \%$ & 77 & \multirow{2}{*}{0.002} \\
Cesarean delivery & 42 & 8 & 27 & $100 \%$ & \\
& $54.5 \%$ & $10.4 \%$ & $35.1 \%$ & 47 & \\
Total & 27 & 14 & 6 & $100 \%$ & \\
\hline
\end{tabular}

The table above showed that in pregnant adolescents delivery by vacuum extraction was referred mostly by doctor (50\%), while in vaginal delivery were referred mostly by midwives $(54.5 \%)$, and in cesarean delivery were also referred mostly by midwives (57.4\%). Statistically with Fisher exact test obtained $\mathrm{p}$ value $<0.05$ which indicated there was a significant relationship between mode of delivery and referral status. Pregnancy in adolescence showed that many people still did not know the risks in teenage pregnancy. Furthermore, delivery at an early age was associated with a greater health risk for the mother.

Based on a household health survey (HHS) in 1995, 21.5\% of Indonesian women had first marriage at the age of 17 years. In rural and urban areas women undertook underage marriages accounted for $24.4 \%$ and $16.1 \%$.

Several studies had shown that the majority of adolescents were trapped in juvenile delinquency shortly after graduating from high school and thus interrupted their personal and daily relationships. Another prevalence was depression that continued to rise from early adolescence to the end that was closely related to the problem of depression in adults [7].

Wellings et al surveyed more than 11,000 men and women aged 16-44 in the UK. They found that $29 \%$ of sexually active young women left school at age 16 without qualifications and had children before the age of 18 , compared with $14 \%$ of women leaving school at age 16 with qualifications and $1 \%$ of women leaving school at the age of 17 years or older [6].

The high number of young marriage was because it was justified by the Marriage Act No. 1 year 1974, the child is considered a teenager when it is mature enough to marry, which legal ages are 16 years for girls and 19 years for boys. Change to this marriage regulation is needed to reduce marriage in adolescence. 
Based on several studies, teenage pregnancies were considered as high-risk pregnancies with an increased risk for the development of pregnancy induced hypertension, preterm delivery, LBW infants, cephalo-pelvic disproportion, operative vaginal delivery, cesarean delivery, and increased perinatal morbidity or mortality. Pregnancy in adolescence is a contributor to maternal and infant mortality in developing countries, including in Indonesia [8].

According to the National Vital Statistics Report in 2001, the rate of LBW infants born to teenage mothers younger than 15 years was 13\% compared with the incidence of $9 \%$ for mothers aged 15-19 years.41 The percentage of LBW infants was also found to be significantly increased when compared with older adolescents and women older than age 20: $14 \%$ vs. $10 \%$ vs. $9 \%$ [9].

Fraser and colleagues reviewed the first pregnancy outcome of a white middle-class 13-to-24year-old mother. Their findings confirmed the influence of socio-demographic factors on reproductive outcomes. Inadequate prenatal care was associated with an increase in preterm delivery rates. Increased risk of premature infants and LBW was also associated with the youngest age group, even in those with the most favorable socioeconomic background, indicating that adequate pregnancy care and improvement in socioeconomic factors did not completely eliminate the medical risks of teenage pregnancies in the youngest age group [10].

\section{Conclusion}

The characteristics of adolescent pregnant women were mostly 17 to 19 years old $(91.5 \%)$ primiparous (96.1\%), married (95.3\%), entered junior high school (47.7\%). Most pregnant teenagers delivered vaginally (52.3\%). Most babies were born with normal birth weight (2500 3500 grams) (64.1\%) and mostly had Apgar score by 8 (70.3\%). Most patients were diagnosed as in labor $(52.3 \%)$.

\section{REFERENCES}

[1] UNICEF., The state of the World's children 2011: adolescence-an age of opportunity. Unicef, 2011.

[2] Asfriyati, "MASALAH KEHAMILAN PRANIKAH PADA REMAJA DITINJAU DARI KESEHATAN REPRODUKSI," http://repository. usu.ac.id /bitstream/123456789/15314/1/ikm-jun2005-\%20(11).pdf, p. 4.

[3] F. Ongela, M. R. Rarung, and R. D. Kandou, "THE ATITUDE AND KNOWLEDGE TOWARDS TEENAGE PREGNANCY OF THREE HIGH SCHOOL IN MANADO CITY," http://download.portalgaruda.org/article.php?article $=146296 \& v a l=1001$.

[4] N. R. Council and C. on Population, Growing up global: The changing transitions to adulthood in developing countries. National Academies Press, 2005.

[5] A. P. WHO, "Unmet needs, undone deeds," A review of the literature and programmes, WHO, Geneva, Switzerland, 2007.

[6] C. S. Christiansen, S. Gibbs, and V. Chandra-Mouli, "Preventing early pregnancy and pregnancy-related mortality and morbidity in adolescents in developing countries: the place of interventions in the prepregnancy period," Journal of pregnancy, vol. 2013, 2013.

[7] J. Rosen, "Position paper on mainstreaming adolescent pregnancy in efforts to make pregnancy safer," World Bank: Washington, DC, 2010. 
[8] F. Ginting and J. Wantania, "Pengetahuan, sikap dan perilaku remaja yang hamil tentang kehamilan remaja di Manado," Buletin IDI Manado, vol. 1, pp. 47-59, 2012.

[9] UNICEF, "Progress for Children: A report card for adolescents, number 10," New York, NY: UNICEF Division of Communication, 2012.

[10]G. C. Patton et al., "Global patterns of mortality in young people: a systematic analysis of population health data," The lancet, vol. 374, no. 9693, pp. 881-892, 2009. 